\title{
Influence of socio-economic factors on emotional changes during the postnatal period
}

\author{
Katarzyna Wszołek', Ewa Żak', Joanna Żurawska', Jolanta Olszewska², Beata Pięta', Iwona Bojar ${ }^{3}$ \\ ${ }^{1}$ Department of Midwifery, University of Medical Sciences, Poznan, Poland \\ ${ }^{2}$ Department of Midwifery Nursing, University of Medical Sciences, Gdansk, Poland \\ ${ }^{3}$ Institute of Rural Health, Lublin, Poland
}

Wszołek KM, Żak E, Żurawska J, Olszewska J, Pięta B, Bojar I. Influence of socio-economic factors on emotional changes during the postnatal period. Ann Agric Environ Med. 2018; 25(1): 41-45. doi: 10.26444/aaem/74486

\begin{abstract}
Objectives. The aim of the study was to identify socio-economic factors that may influence the emotional changes which occur among new mothers in the first days postpartum.

Materials and method. A group of 541 women completed a questionnaire consisting of 30 multiple-choice questions, Edinburgh Postnatal Depression Scale (EPDS), and Hospital Anxiety and Depression Scale (HADS). Statistical calculations were performed with the use of Statistica v.10 and Cytel Studio v. 9.0.0.

Results. The findings revealed the presence of factors which might increase the risk of mood disorders during the postpartum period.

Conclusions. Women who demonstrate warning symptoms should be screened for postnatal emotional changes and mood swings during their hospitalization after delivery. EPDS seems to be a suitable tool for early detection of emotional disturbances.
\end{abstract}

\section{Key words}

postpartum depression, screening and diagnostic tests, public health

\section{INTRODUCTION}

The beginning of the 20th century was marked by social and cultural transformations and the resulting changes within a family. Women, whose major role so far had been to give birth and bring up the children, became professionally active. They started to generate income at a similar or higher level than their partners who, in turn, gained new opportunities in the field of parenting. However, given the biological determinants of reproduction, the role of women remained dominant [1].

Demographic and economic changes, as well as dispersal of families in the western world, are the reasons for the majority of women handling their mothering duties alone, away from the traditional ways of support and groups of friends [2-4].

The role of a mother is strongly incorporated into the social role of a woman, and is usually treated as a biological task which is effortless, or at least unproblematic. However, the period of postpartum does not only bring happiness and fulfillment, in fact, it often triggers emotional disturbances or intensifies existing problems, sometimes with a very rapid course. As a consequence, proper childcare, engagement in the new social role, fulfillment of the already acquired roles, and the functioning of the whole family, are the source of various problems which emerge during that time. Thus, it is vital to offer emotional support to women at this stage to reduce their anxiety and emotional tension.

Numerous emotional and psychological disturbances are observed during the postnatal period. The so-called 'baby blues' occurs within the first days postpartum and is often correlated with breast engorgement due to excessive milk production. Usually, it affects $30 \%-75 \%$ of breastfeeding

Address for correspondence: Katarzyna Wszołek, Department of Midwifery, Jackowskiego 41, 60-512 Poznań, Poland

E-mail: ksiazkimail@gmail.com

Received: 16 January 2016; accepted: 25 May 2016; first published on April 2017 mothers and continues until the second week postpartum [4-16].

Postpartum depression constitutes an important issue in contemporary obstetrics because it affects approximately $10-30 \%$ of all mothers internationally $[5-9,11-18]$. The etiology is multifactorial $[4,5,8,17,19,20]$ and the first symptoms of depression may appear at the end of the first and the beginning of the second month after childbirth $[6,15,16,20,21]$. If undiagnosed and untreated, maternal postpartum depression also has a negative impact on the social, emotional and cognitive development of the child [2224]. Post-traumatic stress disorder (PTSD), the prevalence of which is estimated at $1.5 \%-5.6 \%$, can begin during labour or in the first hours postpartum $[4,16]$. It is observed in people exposed to major stressors, and Beck [24] claims that childbirth is a strong stress factor. Postpartum psychosis is yet another severe mental disorder which may appear during the postpartum period. It affects approximately $0.1-0.2 \%$ of all women and its course is usually rapid and dramatic [4, $8,11,14,16]$. The first symptoms usually appear within the first 2 weeks after labor, sometimes as early as day 3 after childbirth $[8,11,16,30,31]$.

One of the most frequently used questionnaires for early detection of mental disorders among women is the Edinburgh Postnatal Depression Scale (EPDS) [32]. The maximum score of 10 points may be indicative of emotional problems, and women with the score of $12-13$ points are likely to suffer from postpartum depression. Psychiatric or psychological consultation is indicated in such cases, whereas affirmative response to the last question (thoughts about harming oneself), even without the score of $>10$ points, requires the immediate intervention of a psychologist or a psychiatrist $[8,16]$.

The Hospital Anxiety and Depression Scale (HADS) is a simple tool that can be used to evaluate the intensity of anxiety 
and depression [32,33], and may be relevant in assessing symptom intensity. HADS consists of 2 independent scales which measure the level of anxiety and depression. Each of them consists of 7 statements relating to the well-being of the tested person. A score of $0-7$ points is considered as standard, whereas scores between $8-10,11-14$, and 15-21 points indicate gentle, moderate, and severe anxiety or depressive disorders, respectively.

\section{MATERIALS AND METHOD}

The study was conducted among 541 women. An anonymous questionnaire, designed especially for the purpose of the study, was completed by patients of the obstetric wards. The Ethics Committee approved the study (No. 230). All patients gave their informed consent.

The questionnaire included 30 multiple-choice, closed-and open-ended questions. In addition, respondents completed the EPDS and the HADS scales. Moreover, in 2 entries (concerning time before delivery and at the time of filling out the questionnaire) the investigated women could mark emotions they felt and indicate their intensity on a 10-point scale ( 1 - weak, 10 - maximum).

The distribution of value was used to describe the analyzed data. Median, maximum and minimum ranges were used for scores related to feelings pre-and postpartum on a 10-point scale, and the results obtained in EPDS and HADS. Statistical power was calculated with the use of non-parametric tests by comparing the above-mentioned scales and parameters demonstrating growth. The Mann-Whitney $U$ test was used for comparison between the 2 groups. Kruskal-Wallis test with Dunn's multiple comparison test were used to compare 3 and more groups, in order to describe categorical variables; strength was marked as well as percentage values in each category. Contingency tables were created to analyze correlation between variables on a nominal scale. Chi-square test with Yates' continuity correction or Fisher's exact test were used for $2 \times 2$ tables, whereas Pearson's chi-square test or the Fisher-Freeman-Halton test were used for tables larger than $2 \times 2$. Non-parametric Spearman's rank based correlation quotient was used to analyze the relationship between depression and anxiety scales in HADS and EPDS. Statistical significance level was estimated at $\alpha=0.05$. Calculations were made with the use of Statistica v. 10 and Cytel Studio v. 9.0.0. at the Department of Computer Science and Statistics, Poznan University of Medical Sciences.

\section{RESULTS}

Mean patient age was 30 years, with the youngest and the oldest respondents at the age of 17 and 44, respectively. As far as the place of residence was concerned, $74 \%$ of the women were city-dwellers whereas $26 \%$ were inhabitants of rural areas. Pregnancy was planned by $83 \%$ of the respondents, while $17 \%$ declared their pregnancy to be unintended. The study found no correlation between age, place of residence, and planned vs. unintended pregnancy, vs. EPDS and HADS scores and the occurrence of the investigated emotions after childbirth (Tab. 1).

As far as education was concerned, $74 \%$ of the respondents had higher education, while $22 \%$ and $4 \%$ had secondary
Table 1. Certain factors vs. EPDS, HADS-A and HADS-D

\begin{tabular}{|c|c|c|c|}
\hline Scale & EPDS & HADS-A & HADS-D \\
\hline Age & $p=0.9268$ & $p=0.9648$ & $p=0.9846$ \\
\hline Place of residence (city/rural area) & $p=0.3060$ & $p=0.9588$ & $p=0.6583$ \\
\hline Planned/unplanned pregnancy & $p=0.6198$ & $p=0.3983$ & $p=0.7040$ \\
\hline
\end{tabular}

and primary education, respectively. A positive correlation between the feelings of joy, peace, contentment, admiration, pride, happiness, love for the child/children, sadness, helplessness, unwillingness, despondency and the level of education was demonstrated (Tab 2).

Table 2. Emotions and feelings vs. level of education

\begin{tabular}{lcccc}
\hline $\begin{array}{l}\text { Emotions and } \\
\text { feelings after } \\
\text { childbirth }\end{array}$ & $\begin{array}{c}\text { Primary } \\
\text { education } \\
\mathrm{n}=21(4 \%)\end{array}$ & $\begin{array}{c}\text { Secondary } \\
\text { education } \\
\mathrm{n}=118(22 \%)\end{array}$ & $\begin{array}{c}\text { Higher } \\
\text { education }\end{array}$ & $\begin{array}{c}\text { Statistical } \\
\text { significance } \\
(\mathrm{p})\end{array}$ \\
\hline joy & $\mathrm{n}=16(76.2 \%)$ & $\mathrm{n}=112(94.9 \%)$ & $\mathrm{n}=374(93 \%)$ & 0.0087 \\
\hline peace of mind & $\mathrm{n}=11(52.4 \%)$ & $\mathrm{n}=93(78.8 \%)$ & $\mathrm{n}=308(76.6 \%)$ & 0.0295 \\
\hline contentedness & $\mathrm{n}=12(57.1 \%)$ & $\mathrm{n}=99(83.9 \%)$ & $\mathrm{n}=314(78.1 \%)$ & 0.0206 \\
\hline admiration & $\mathrm{n}=10(47.6 \%)$ & $\mathrm{n}=87(73.7 \%)$ & $\mathrm{n}=273(67.9 \%)$ & 0.0553 \\
\hline pride & $\mathrm{n}=9(43 \%)$ & $\mathrm{n}=97(82.2 \%)$ & $\mathrm{n}=304(75.6 \%)$ & 0.0005 \\
\hline $\begin{array}{l}\text { love for the } \\
\text { child/children }\end{array}$ & $\mathrm{n}=13(61.9 \%)$ & $\mathrm{n}=114(96.6 \%)$ & $\mathrm{n}=372(92.5 \%)$ & $<0.001$ \\
\hline sadness & $\mathrm{n}=2(9.5 \%)$ & $\mathrm{n}=13(11 \%)$ & $\mathrm{n}=89(22.1 \%)$ & 0.0136 \\
\hline helplessness & $\mathrm{n}=3(14.3 \%)$ & $\mathrm{n}=18(15.3 \%)$ & $\mathrm{n}=104(25.9 \%)$ & 0.0343 \\
\hline unwillingness & $\mathrm{n}=0$ & $\mathrm{n}=5(4.2 \%)$ & $\mathrm{n}=43(10.7 \%)$ & 0.0328 \\
\hline despondency & $\mathrm{n}=2(9.5 \%)$ & $\mathrm{n}=11(9.3 \%)$ & $\mathrm{n}=73(18.1 \%)$ & 0.0499 \\
\hline
\end{tabular}

In the group with primary education, $3.1 \%$ scored $<10$ points in the EPDS vs. $6.4 \%$ who scored $\geq 10$ points, while among women with secondary education the results were $20.2 \%$ vs. $27 \%$, and in the group with higher education the results were $76.6 \%$ vs. $66.7 \%$, respectively. Respondents who scored $<10$ points in EPDS were less likely to be in bad financial situation than women who received $\geq 10$ points, and those in an average financial situation scored similarly. Women who gained $<10$ points in EPDS were more often in a good or very good financial situation in contrast to women who scored $\geq 10$ points (Tab. 3 ).

Table 3. EPDS vs. level of education and financial situation

\begin{tabular}{|c|c|c|c|}
\hline & $\begin{array}{c}<10 \text { points inEPDS } \\
n=415(77 \%)\end{array}$ & $\begin{array}{c}\geq 10 \text { points in EPDS } \\
n=126(23 \%)\end{array}$ & $\begin{array}{l}\text { STATISTICAL } \\
\text { SIGNIFICANCE } \\
\text { (p) }\end{array}$ \\
\hline education & $\begin{array}{c}\text { primary education } \\
n=13(3.1 \%) \\
\text { secondary education } \\
n=84(20.2 \%) \\
\text { higher education } \\
n=318(76.6 \%)\end{array}$ & $\begin{array}{c}\text { primary education } \\
n=8(6.4 \%) \\
\text { secondary education } \\
n=34(27 \%) \\
\text { higher education } \\
n=84(66.7 \%)\end{array}$ & 0.0201 \\
\hline $\begin{array}{l}\text { financial } \\
\text { situation }\end{array}$ & $\begin{array}{c}\text { badn }=1(0.2 \%) \\
\text { average } n=59(14.2 \%) \\
\text { good } n=291(70.1 \%) \\
\text { very good } n=64(15.4 \%)\end{array}$ & $\begin{array}{c}\text { bad } n=2(1,6 \%) \\
\text { average } n=29(23 \%) \\
\text { good } n=81(64.3 \%) \\
\text { very good } n=14(11.1 \%)\end{array}$ & 0.0096 \\
\hline
\end{tabular}

Also, a correlation between the financial situation and anxiety and depressive disorders could be observed using the anxiety (HADS-A) and depression scale (HADS-D) (Tab. 4). 
Table 4. Financial situation vs. the HADS-A and HADS-D scores

\begin{tabular}{|c|c|c|c|c|c|}
\hline & \multicolumn{5}{|c|}{ HADS-A } \\
\hline & $\begin{array}{c}\text { Normal } \\
\mathrm{n}=428(79.1 \%)\end{array}$ & $\begin{array}{c}\text { Mild } \\
\mathrm{n}=73(13.5 \%)\end{array}$ & $\begin{array}{c}\text { Medium } \\
\mathrm{n}=26(4.8 \%)\end{array}$ & $\begin{array}{c}\text { Severe } \\
n=14(2.6 \%)\end{array}$ & $\begin{array}{l}\text { Statistical } \\
\text { significance } \\
\text { (P) }\end{array}$ \\
\hline \multirow[t]{3}{*}{$\begin{array}{l}\text { financial } \\
\text { situation }\end{array}$} & $\begin{array}{l}\text { bad } n=1(0.2 \%) \\
\text { average } n=54(12.6 \%) \\
\text { good } n=305(71.3 \%) \\
\text { very good } n=68(15.9 \%)\end{array}$ & $\begin{array}{c}\text { bad } n=2(2.7 \%) \\
\text { average } n=19(26 \%) \\
\text { good } n=45(61.6 \%) \\
\text { very good } n=7(9.6 \%)\end{array}$ & $\begin{array}{l}\text { bad } n=0 \\
\text { average } n=10(38.5 \%) \\
\text { good } n=13(50 \%) \\
\text { very good } n=3(11.5 \%)\end{array}$ & $\begin{array}{c}\text { bad } n=0 \\
\text { average } n=5(35.7 \%) \\
\text { good } n=9(64.3 \%) \\
\text { very good } n=0\end{array}$ & $<0.001$ \\
\hline & \multicolumn{5}{|c|}{ HADS-D } \\
\hline & $\begin{array}{c}\text { Normal } \\
\mathrm{n}=502(92.8 \%)\end{array}$ & $\begin{array}{c}\text { Mild } \\
\mathrm{n}=27(4.9 \%)\end{array}$ & $\begin{array}{c}\text { Medium + Severe } \\
\mathrm{n}=12(1.5 \%)\end{array}$ & $\begin{array}{l}\text { Statistical significance } \\
(p)\end{array}$ & \\
\hline $\begin{array}{l}\text { financial } \\
\text { situation }\end{array}$ & $\begin{array}{c}\text { bad } n=2(0.4 \%) \\
\text { average } n=74(14.7 \%) \\
\text { good } n=352(70.1 \%) \\
\text { very good } n=74(14.7 \%)\end{array}$ & $\begin{array}{c}n=0 \\
n=8(29.6 \%) \\
n=16(59.3 \%) \\
n=3(11.1 \%)\end{array}$ & $\begin{array}{c}n=1(8.3 \%) \\
n=6(50 \%) \\
n=4(33.3 \%) \\
n=1(8.3 \%)\end{array}$ & 0.0018 & \\
\hline
\end{tabular}

Married women constituted the largest group of respondents (80\%), followed by their unmarried (17\%), and divorced (3\%) peers. A correlation between the feelings of happiness, and love for the child/children and maternal marital status was found (Tab. 5).

Table 5. Emotions and feelings vs. marital status

\begin{tabular}{lcccc}
\hline $\begin{array}{l}\text { Emotions and feelings } \\
\text { after childbirth }\end{array}$ & $\begin{array}{c}\text { Married } \\
\mathrm{N}=433(80 \%)\end{array}$ & $\begin{array}{c}\text { Single } \\
\mathrm{N}=92(17 \%)\end{array}$ & $\begin{array}{c}\text { Divorced } \\
\mathrm{N}=16(3 \%)\end{array}$ & $\begin{array}{c}\text { Statistical } \\
\text { significance } \\
(\mathrm{P})\end{array}$ \\
\hline happiness & $\begin{array}{c}\mathrm{n}=391 \\
(90.3 \%)\end{array}$ & $\begin{array}{c}\mathrm{n}=72 \\
(78.3 \%)\end{array}$ & $\begin{array}{c}\mathrm{n}=13 \\
(81.3 \%)\end{array}$ & 0.0038 \\
\hline $\begin{array}{l}\text { love for the child/ } \\
\text { children }\end{array}$ & $\mathrm{n}=405(93.5 \%)$ & $\begin{array}{c}\mathrm{n}=79 \\
(85.9 \%)\end{array}$ & $\begin{array}{c}\mathrm{n}=15 \\
(93.8 \%)\end{array}$ & 0.0433 \\
\hline
\end{tabular}

The respondents also supplied information about who will help them take care of the child after giving birth: $80 \%$ - husband, $60 \%$ - mother, $18 \%$ - partner, $24 \%$ - motherin-law, $15 \%$ - sister, $4 \%$ - friend, whereas $2 \%$ of the women declared they would be taking care of the newborn alone. A partner's mother, a visiting midwife, an older child, and a babysitter were also indicated as potential helpers (other - 7\%). Women who scored $<10$ points in EPDS were more likely to obtain a declaration of support from the husband in terms of childcare arrangements after birth, compared to their peers who scored $\geq 10$ points. An inverse relationship was obtained when analyzing the assistance of the partner after childbirth. Women who declared their partner's help after delivery more often scored $\geq 10$ points in EPDS. Women whose EDPS score was $\geq 10$ points more often declared that after delivery they would nurse their child alone, compared to women whose total score was $<10$ points (Table 6 ).

The obtained results also revealed a correlation between declaration of help in childcare arrangements from the mothers of the respondents and their feelings before birth.

Table 6. EPDS vs. declaration of support

\begin{tabular}{lccc}
\hline & $\begin{array}{c}<10 \text { points in EPDS } \\
\mathrm{n}=415(77 \%)\end{array}$ & $\begin{array}{c}\geq 10 \text { points in EPDS } \\
\mathrm{n}=126(23 \%)\end{array}$ & $\begin{array}{c}\text { Statistical } \\
\text { significance } \\
(\mathrm{p})\end{array}$ \\
\hline $\begin{array}{lccc}\text { who will help to } \\
\text { take care of the } \\
\text { newborn after } \\
\text { giving birth }\end{array}$ & husband $\mathrm{n}=342(82.4 \%)$ & $\mathrm{n}=90(71.4 \%)$ & 0.0103 \\
\cline { 2 - 4 } & partner $\mathrm{n}=65(15.6 \%)$ & $\mathrm{n}=33(26.2 \%)$ & 0.0106 \\
\cline { 2 - 4 } & no help $\mathrm{n}=3(0.8 \%)$ & $\mathrm{n}=5(3.4 \%)$ & 0.0262 \\
\hline
\end{tabular}

Table 7. Emotions and feelings before delivery vs. declaration of support from respondent's mother

\begin{tabular}{lccc}
\hline \multirow{2}{*}{$\begin{array}{l}\text { Emotions and feelings } \\
\text { before childbirth }\end{array}$} & \multicolumn{2}{c}{\begin{tabular}{c} 
Yeclaration of help from the mother \\
\cline { 2 - 3 }
\end{tabular}} & $\begin{array}{c}\text { Statistical } \\
\text { significance } \\
(\mathrm{p})\end{array}$ \\
\hline joyful expectation & $\mathrm{n}=250(60 \%)$ & $\mathrm{n}=219(40 \%)$ & 0.0010 \\
\hline Sensitivity & $\mathrm{n}=211(65.5 \%)$ & $\mathrm{n}=119(54.3 \%)$ & 0.0088 \\
\hline pride & $\mathrm{n}=199(61.8 \%)$ & $\mathrm{n}=113(51.6 \%)$ & 0.0183 \\
\hline love for the child/children & $\mathrm{n}=267(82.9 \%)$ & $\mathrm{n}=166(75.8 \%)$ & 0.0419 \\
\hline responsibility & $\mathrm{n}=236(73.3 \%)$ & $\mathrm{n}=139(63.5 \%)$ & 0.0150 \\
\hline
\end{tabular}

The women who had received such declarations more often experienced joyful expectation, sensitivity, pride, feelings of love for the child/children, and responsibility, contrary to the respondents who did not expect to receive such help (Tab. 7).

\section{DISCUSSION}

Socio-economic status and psychosocial factors have a wellknown impact on the incidence of postnatal mood disorders. According to some authors, people in a good socio-economic situation generally live longer and are characterized by good health. In this context, Kaczmarczyk-Chałas et al. [39] acknowledge that the level of education is one of the strongest indicators of health status.

In the presented study population, the group of women with higher education rarely scored $\geq 10$ points in EPDS, contrary to respondents with primary, vocational, and secondary education, who more frequently scored $\geq 10$ points. A similar relationship is indicated by Kaźmierczak et al. [5], Baston et al. [11], Jaeschke et al. [13], and Chrzan-Dętkoś et al. [19]. Reroń et al. [17] noted that women with secondary education are at the highest risk of developing postpartum depression. However, Bałkowiec-Iskra et al. [36], argue that the level of maternal education has no effect on the incidence of postpartum depression.

A surprising correlation was observed with regard to the feelings of sadness, sense of helplessness, unwillingness, and depression after giving birth. These postpartum emotions appeared most often among women with higher education, compared to their peers with secondary and primary education. Concurrently, women with higher education 
less frequently scored $\geq 10$ points in EPDS, in comparison with those with primary and secondary education, which may indicate a greater capability of the former to cope with negative emotions. No correlation was observed between education and depression and anxiety HADS scores.

The financial situation of the respondents has a significant impact on their emotional state after giving birth. In the current study population, women who scored $<10$ points were less likely to be in bad financial situation than women who obtained $\geq 10$ points. Similarly, in HADS, women with a better financial status were less likely to suffer from severe symptoms of anxiety or depression. A similar relationship was reported by Czerwiak et al. [29] Iwanowicz-Palus et al. [18], Krzyżanowska-Zbucka [15], Chrzan-Dętkoś et al. [19], and Baston et al. [11], also pointed out that a bad financial situation is observed more often among women who experience postnatal mood disorders. Bergant et al. [9] generally concluded that women of lower social status are characterized by an increased risk of postpartum depression. Moreover, Makara-Studzińska et al. [40] observed that a bad financial situation may even induce very strong anxiety in the third trimester of pregnancy.

An attempt was also made in the presented study to analyze the impact of marital status and help in childcare arrangements on the pre- and postnatal emotions and the EPDS and HADS scores. Based on the obtained results, it is safe to conclude that marital status does not have significant influence on the incidence of postnatal mood disorders. Support from friends and family proved to be the most important factor. Women who received a declaration of help from their mothers before giving birth were more likely to feel joy of expectation, sensitivity, pride, love for the child/ children, and responsibility, in contrast to women who received no such declaration of support.

The effect of the relationship between a woman and her mother on the prevalence of postpartum depression has been emphasized in the literature. Chrzan-Dętkoś et al. [19], showed that women who received care from their mothers during childhood had lower EPDS scores. Similarly, Blum [37] noted that women who demonstrated symptoms of postpartum depression were more likely to negatively assess the quality of care exercised over them by their mothers. Blum also pointed out that lack of adequate paternal care during childhood can have a similar effect on the prevalence of depressive disorders after giving birth. Gebuza et al. [35] included bad relationship with the mother into the group of stress-promoting factors, thus increasing the risk of postpartum depression.

As study by Kosińska-Kaczyńska et al.[8], also did not reveal any statistically significant differences between women who scored $<10$ and $\geq 10$ points in EPDS and their marital status. However, a correlation between the obtained results and support from the husband or partner was observed. Similar observations were made by Kaźmierczak et al. [5], who included bad marital relationship or lack of a husband into the socio-economic factors causing stress. Guszkowska [38] also indicated that bad relations with a partner can result in PTSD, lack of satisfaction with childbirth, and postpartum depression. Baston et al. [11] emphasized the lack of support from the environment and absence of a life partner. Krzyżanowska-Zbucka [15] included psychosocial factors, such as lone motherhood and bad relationships in the family, into the group of risk factors for postpartum depression, similar to Jaeschke et al.[13] and Iwanowicz-
Palus et al. [18], suggested careful observation of women who declared they would bring up their child alone. Snow [4] and Rokach [2] observed that a bad marriage constitutes a risk factor for the prevalence of mental disorders during the postpartum period, which was also stressed by Blum[37]. However, Reroń et al. [17], did not indicate marital status as a factor that could affect the prevalence of depressive disorders.

Women who declared they would receive support in childcare arrangements from the partner were more likely to obtain $\geq 10$ points in EPDS, compared to those who were to receive help from the husband. At this point, it is worth recalling the study by Podolska et al.[34], who found the risk of developing postpartum depression to be several times higher among women in informal relationships, compared to their married peers. These authors claim that such patients should be subjected to screening for early detection of postnatal mood disorders.

In the current study, no correlation was observed between results in EPDS, HADS and emotion and feelings after delivery and patients' place of residence; the same as Kosińska-Kaczyńska et al. [8], Podolska et al. [34], Gebuza et al. [35]. However, Reroń et al. [17] noted that postpartum depression occurs significantly more frequently among big city-dwellers than among the inhabitants rural of areas.

\section{CONCLUSIONS}

1. Early detection of postpartum emotional changes and mood swings may be possible by identifying their promoting factors.

2. Socio-economic factors which in various ways increase the risk of postpartum mood swings and emotional changes, include: lack of support from the mother, lone motherhood, partnership, low level of education, and low financial status.

3. Women who demonstrate the above-mentioned risk factors should be submitted to a screening test for postnatal emotional changes and mood swings already during the postpartum hospitalization. EPDS is a reliable tool to detect these disturbances early.

4. Age, place of residence (rural or city areas) and unplanned pregnancy did not have any influence on scores achieved by lying-in women in EPDS and HADS.

\section{REFERENCES}

1. Gębka M. Miejsce ojca w procesie prokreacji - droga ku równości czy zagrożenie dyskryminacją. In: Marchlewska K, Wedeł-Domaradzka A, eds. Studia i analizy europejskie. Półrocznik naukowy poświęcony zagadnieniom polityki równości Unii Europejskiej, Bydgoszcz 2011; 1(7): 89-100.

2. Rokach A. Giving life: loneliness, pregnancy and motherhood. Social Behavior and Personality. An International Journal 2004; 32(7): 691702 .

3. Office for National Statistics Birth Statistics: Review of the Registrar General on British and Patterns of Family Building in England and Wales. Her Majesty'sStationery Office, London 2004.

4. Snow S. Zdrowie psychiczne w okresie okołoporodowym. In: Edwins J, eds. Praktyka zawodowa. Biblioteka Położnej. Wydawnictwo Lekarskie PZWL, Warszawa 2008: 187-208.

5. Kaźmierczak M, Gebuza G, Gierszewska M. Zaburzenia emocjonalne okresu poporodowego. Probl Pielęg. 2010; 18(4): 503-511.

6. Brockington IF. Postpartum psychiatric disorders. Lancet 2004; 363 : 303-310. 
7. Miller LJ. Postpartum depression. JAMA 2002; 287(6): 762-765.

8. Kosińska-Kaczyńska K, Horosz E, Wielgoś M, Szymusik I. Zaburzenia afektywne u położnic w pierwszym tygodniu po porodzie - analiza rozpowszechnienia i czynników ryzyka. Ginekol Pol. 2008; 79: 182-185.

9. Bergant AM, Heim K, Ulmer H, Illmensee K. Early postnatal depressive mood: associations with obstetric and psychosocial factors. J Psychosom Res. 1999; 46(4): 391-394.

10. Richardson D. Women, Motherhood and Childrearing. MacMillan, London 1993.

11. Baston H, Hall J. Midwifery Essentials Labor. Elsevier Limited, London 2009.

12. Hannah P, Adams D, Lee A, Glover V, Sandler M. Links Between Early Post-partum Mood and Postnatal Depression. Br J Psychiatry 1992; 160: 777-780.

13. Jaeschke R, Siwek M, Dudek D. Poporodowe zaburzenia nastroju update 2012. Neuropsychiatr Neuropsycholog. 2012; 7(3): 113-121.

14. Robertson E, Grace S, Wallington T, Stewart DE. Antenatal risk factors for postpartum depression: a synthesis of recent literature. Gen Hosp Psychiat. 2004; 26: 289-295.

15. Krzyżanowska-Zbucka J. Problemy emocjonalne kobiet w okresie okołoporodowym. Fundacja Rodzić po Ludzku, Warszawa 2008.

16. Mojs E, Czarnecka-Iwańczuk M, Głowacka MD. Poziom lęku jako stanu i cechy oraz depresji we wczesnym połogu - doniesienia wstępne. Psychiatr Pol. 2013; 47(1): 31-40.

17. Reroń A, Gierat B, Huras H. Ocena częstotliwości występowania depresji poporodowej. Ginekol Prakt. 2004; 3: 32-35.

18. Iwanowicz-Palus G, Bień A. Psychoprofilaktyka u kobiet w ciąży. In: Bień A, ed. Opieka nad kobietą ciężarną. Wydawnictwo Lekarskie PZWL, Warszawa 2009: 342-361.

19. Chrzan-Dętkoś M, Dyduch-Maroszek A, Humięcka A, Karasiewicz K. Uwarunkowania i konsekwencje depresji poporodowej. Psychoterapia 2012; 2(161): 55-63.

20. Jardri R, Pelta J, Maron M, et al. Predictive validation study of the Edinburgh Postnatal Depression Scale in the first week after delivery and risk analysis for postnatal depression. J Affec Disorders 2006; 93(1-3): 169-76.

21. Affonso DD, De AK, Horowitz JA, Mayberry LJ. An international study exploring level of postpartum depressive symptomatology. J Psychosom Res 2000; 49: 20716.

22. Bielawska-Batorowicz E. Psychologiczne aspekty prokreacji. „Śląsk” Wydawnictwo Naukowe, Katowice 2005: 221-242.

23. Kossakowska-Petrycka K. Adaptacja polskiej wersji kwestionariusza oceny ryzyka depresji poporodowej. Post Psychiatr Neurol. 2007; 16(4): 303-308.

24. Beck C. Post-traumatic stress disorder due to childbirth: the aftermath. Nurs Res. 2004; 53(4): 216-224.
25. Ryding E, Wijma B, Wijma K. Post-traumatic stress reactions after emergency caesarean section. Acta Obstet Gyn Scan 1997; 76: 856-861.

26. MacLean L, McDermott M, May C. Method of delivery and subjective distress: women's emotional responses to childbirth practices. J Reprod Infant Psyc. 2000; 18: 153-162.

27. Söderquist J, Wijma K, Wijma B. Traumatic stress after childbirth: the role of obstetric variables. J Psychosom Obst Gyn. 2002; 23(1):31-39.

28. Crompton J. Post-traumatic stress disorder and childbirth. BJM 1996; 4: $290-293$

29. Czerwiak G, Michlska M, Zdziebło K. Problemy emocjonalne związane z porodem.Ann Acad Med Siles. 2006; 60(1): 31-34.

30. Cox JL, Holden JM, Sagovsky R. Detection of postnatal depression: development of the 10-item Edinburgh Postnatal Depression Scale. Brit J Psychiat. 1987; 150: 782-786.

31. Pięta B, Jurczyk MU, Wszołek K, Opala T. Emotional changes occurring in women in pregnancy, parturition and lying-in period according to factors exerting an effect on a woman during the peripartum period. Ann Agric Environ Med. 2014; 21(3): 661-665.

32. Zigmond AS, Snaith RP. The Hospital Anxiety and Depression Scale. Acta Psychiat Scand. 1983; 67: 361-370.

33. Bedford A, de Pauw K, Grant E. The structure of the Hospital Anxiety and Depression Scale (HADS): an appraisal with normal, psychiatric and medical patient subjects. Pers Indiv Differ. 1997; 23(3): 473-478.

34. Podolska MZ, Majkowicz M, Sipak-Szmigiel O, Ronin-Walknowska E. Kohabitacja jako silny czynnik predykcyjny depresji okołoporodowej. Ginekol Pol. 2009; 80(4): 280-284.

35. Gebuza G, Kaźmierczak M, Gierszewska M, Michalska E. Problemy kobiet w połogu i ich przyczyny. Perinatol Neonatol Ginekol. 2010; 3(4): 290-295.

36. Bałkowiec-Iskra E, Niewada M. Depresja poporodowa - rozpoznawanie i leczenie. Przew Lek. 2002; 5(11/12): 104-110.

37. Blum LD. Psychodynamics of postpartum depression. Psychoanal Psychol 2001; 24(1): 45-62.

38. Guszkowska M. Lęk przed porodem i determinujące go czynniki. Perinatol Neonatol Ginekol. 2012; 5(3): 154-161.

39. Kaczmarczyk-Chałas K, Baryła M, Bielecki W, Drygas W, Stelmach W. Wykształcenie a zdrowie - czynniki warunkujące korzystanie ze świadczeń zdrowotnych wśród podopiecznych Łódzkiej Regionalnej Kasy Chorych. Menedżer Zdrowia 2003; 5: 68-71.

40. Makara-Studzińska M, Morylowska-Topolska J, Sygit K, Sygit M, Goździewska M. Socio-demographical and psychosocial determinants of anxiety symptoms in a population of pregnant women in the regions of central and eastern Poland. Ann Agric Environ Med. 2013; 20(1): 195-202. 